\title{
Gordon Morris
}

University of Exeter

\section{Reclaiming Local Democracy: A progressive future for local government by Ines Newman}

(Policy Press, ISBN 978-1447308904 price £19.99)

https://policypress.co.uk/reclaiming-local-democracy

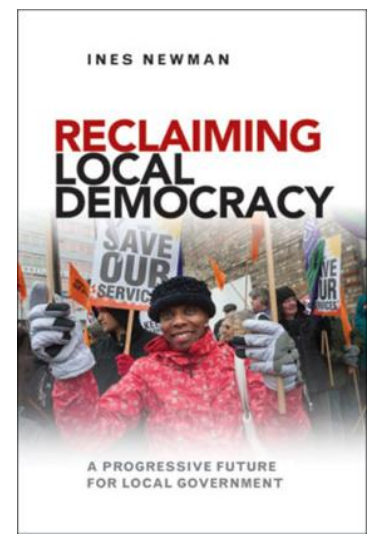

This is a book that needed to be written. First published in 2014, Ines Newman takes a timely, refreshing, and broad look at local government. Although it relates mainly to the UK, colleagues throughout the Commonwealth will find this book both interesting and relevant. Her thoughtful approach has, I think, optimism at its heart. The work is an effective counterpoint to the prevailing neoliberal orthodoxy that "austerity", with its consequential public sector cuts, is unavoidable. As Newman makes clear, "austerity" is a political choice.

Her challenge to councillors and officers is to turn away from the long-established focus on targets and efficiency measures imposed by central government. Instead, she urges them to build on the work of the early proponents of local government, such as Birmingham's Chamberlain family, and to draw on the vision (and anger) of the likes of George Lansbury who, as mayor of Poplar in London in the years after the First World War, fought for a fairer distribution of income between rich and poor. Other examples are cited of local government politicians challenging central government diktats. Newman, I sense, would like more of this!

The book is useful mix of theory and practice, with plenty of case study material. It is likely to appeal to the general reader, as well as to students, Newman's fellow academics, and councillors and officials. It is sufficiently - deliberately - provocative to stimulate debate, and is all the better for that.

(C) 2016 Gordon Morris. This is an Open Access article distributed under the terms of the Creative Commons Attribution 4.0 Unported (CC BY 4.0) License (https://creativecommons.org/licenses/by/4.0/), allowing third parties to copy and redistribute the material in any medium or format and to remix, transform, and build upon the material for any purpose, even commercially, provided the original work is properly cited and states its license. 
The book takes the reader on a journey. This starts with an overview of UK local government's decline from a position of relative apolitical autonomy and freedom from central government control, to today's contradictory position, where rhetoric around notions of (so-called) "localism" coincides with budget cuts and the proposed forced "academisation" of schools. Newman explains how, in the intervening period, local government became increasingly politicised, central government's control grew, and managerialism encouraged local authorities to move from service delivery to commissioning other, usually private sector, organisations as service providers.

This background is used as the foundation stone on which Newman builds her main argument. She makes the case that injustice and inequality eventually harm everyone, rich as well as poor (although, clearly, it is the latter who suffer most), and that, therefore, an ethical framework centred on needs, rights, social justice (fairness) is needed. It is her contention that councillors and their officers, at a time when the private sector is, in her view, too dominant (case studies are given in support of this contention), have the potential - and the duty - to develop and implement such a framework.

Following this, Newman devotes a lengthy chapter to developing, "... an ethical framework that can act as a guide for councillors, municipal leaders and officers ..." (p. 72). This is her personal take on the undoubted challenges facing those who seek to persuade neoliberals that an alternative approach is necessary, desirable, and possible. The framework consists of a series of questions relating to policy development. They are worth listing:

\section{Does the policy ...}

... rest on a firm ethical foundation?

... reinforce mutual obligations through universal provision?

... address right?

... address distributive justice?

... lead to a deeper understanding of citizenship and the common good?

$\ldots$ address recognition and emancipation?

... help professionals deal with day-to-day ethical problems?

... consider future generations and promote sustainability?

At the heart of this is Newman's concern about inequality; about how the voices of the rich and powerful (the elites) dominate in today's world. This is to the detriment of the poor. Their relatively precarious financial and employment circumstances clearly limit their freedom to participate fully in, for example ... local government. 
Newman argues that if local democracy is to be reclaimed from a market-dominated politics and business elites, councillors, so long seen as - essentially - agents of central government responsible for hitting centrally-imposed targets, while grappling with reducing budgets, will, “...need to address power inequalities and to increase the capacity of individuals or groups to engage in the policy process" (p. 101). Several case studies illustrate how local authorities are attempting to reach out to their constituents. The point is also made, however, that most change comes from outside organisations; increasingly, today, via social media. Consequently, government must listen to and work with social and community groups.

The book concludes by reiterating the point that citizens must be involved in determining policy direction for democracy to work properly. Overall, the book offers some evidence to suggest that all is not lost, but there is clearly a long way to go. To an extent it is unfair to expect local government, so closely controlled by central government, to solve the current problems of democracy. However, to take a positive view, the sheer number of councils, their closeness to the people and their variety across the tiers from parish to city, via district, borough, and county, means that there is scope for innovation, and progress.

It is to be hoped that enough people, be they councillors, officers, students, or simply the generally interested, read this thought provoking, informative book. 